\title{
Systemic Resistance to Gray Mold Induced in Tomato by Benzothiadiazole and Trichoderma harzianum T39
}

\author{
Yael Meller Harel, Zeraye Haile Mehari, Dalia Rav-David, and Yigal Elad
}

Department of Plant Pathology and Weed Research, Agricultural Research Organization, The Volcani Center, Bet Dagan 50250, Israel. Current address of Y. Meller Harel: Ministry of Agriculture and Rural Development, Plant Protection and Inspection Services, P.O. Box 78, Bet Dagan 50250, Israel.

Current address of Z. Haile Mehari: Fondazione E. Mach, San Michele all'Adige, TN, Italy.

Accepted for publication 12 September 2013.

\begin{abstract}
Meller Harel, Y., Haile Mehari, Z., Rav-David, D., and Elad, Y. 2014. Systemic resistance to gray mold induced in tomato by benzothiadiazole and Trichoderma harzianum T39. Phytopathology 104:150-157.

Gray mold (Botrytis cinerea) is an important disease of tomato (Solanum lycopersicum). This study examined defense-related gene expression involved in the resistance to $B$. cinerea that is induced in tomato plants by benzothiadiazole and Trichoderma harzianum T39 soil drench. In whole plants, transcriptional changes related to salicylic acid and ethylene were induced by the application of a $0.01 \%$ benzothiadiazole solution, whereas changes related to jasmonic acid were induced

after pathogen inoculation, the plants that had received the 0.04\% T39 drench exhibited $62 \%$ less severe disease than the untreated plants. The $0.4 \% \mathrm{~T} 39$ drench led to an $84 \%$ reduction in disease severity. Observations of $B$. cinerea infection in leaves harvested from plants grown in the treated soils revealed that drenching with a T39 suspension induces systemic resistance against $B$. cinerea and primes salicylic acid- and ethylene-related gene expression in a manner proportional to the concentration of the biocontrol agent. Benzothiadiazole treatment induced resistance to gray mold independently of salicylic acid and led to strong priming of two genes known to be involved in defense against $B$. cinerea, Pti5 and PI2.
\end{abstract} by the application of a $0.4 \%$ T39 suspension. On detached leaves, soil treatment by T39 led to enhanced resistance to $B$. cinerea infection that was proportional to the concentration of the T39 suspension. By 5 days
Additional keywords: control agents.
Upon exposure to biotic or abiotic stimuli, plants' innate defenses against pathogens or pests can be strengthened in a systemic manner, leading to the physiological state of induced resistance (IR). IR is usually reached through two main physiological routes, systemic acquired resistance (SAR) or induced systemic resistance (ISR), which, in model plant systems, can be differentiated by the nature of the elicitor and the regulatory pathways involved. SAR usually occurs following an earlier localized attack by a pathogen that is characterized by the accumulation of the phytohormone salicylic acid (SA), the activation of pathogenesisrelated (PR) gene expression, and, often, the development of a necrotic region at the site of the pathogen entry, which is known as the hypersensitive response (13). ISR begins with the colonization of plant roots by beneficial soilborne microorganisms such as plant growth-promoting rhizobacteria and fungi (55). It involves the phytohormones ethylene (ET) and jasmonic acid (JA) and is generally associated with a physiological state in which plants can react more efficiently to pathogen attack; that is, the priming of plant defense mechanisms (11). Primed defense reactions include an earlier oxidative burst and stronger upregulation of defense-related genes (3). Although more often associated with the ISR pathway, priming can also be induced by SAR activators such as SA and its chemical analogues, as well as various other molecules (26).

SA activates the SAR response via a complex signaling cascade that leads to the induction of the expression of PR genes (36). SA-

Corresponding authors: Y. Meller Harel; E-mail address: yaelm@moag.gov.il Y. Elad; E-mail address: elady@volcani.agri.gov.il

http://dx.doi.org/10.1094/PHYTO-02-13-0043-R

(C) 2014 The American Phytopathological Society analogues such as benzothiadiazole (BTH) and its derivative acibenzolar-S-methyl (ASM) are assumed to activate SAR through a similar pathway $(32,48)$. The efficacy of BTH and ASM as control agents has been demonstrated in various pathosystems such as squash (Curbita pepo)-Phytophthora blight (25), pea (Pisum spp.)-Uromyces pisi (8), grapevine (Vitis vinera)-Plasmopara viticola (44), and eucalyptus (Eucalyptus spp.)-Puccinia psidii (9). In tomato, spray applications of SA analogues have been found to effectively control gray mold (Botrytis cinerea) $(2,39)$. These compounds have also been shown to be effective when seed were sown in treated soil $(2,7)$, when used as a stand-alone seed treatment, or when integrated with applications of the plant growth-promoting rhizobacterium Pseudomonas fluorescence (1). Studies of the defense pathway activated by the SA analogues for IR against $B$. cinerea are scarce. In one study, early and enhanced generation of reactive oxygen species as well as an increase in peroxidase activity were found to be important in IR to $B$. cinerea in tomato (39).

Trichoderma spp. are established plant growth-promoting fungi that suppress plant diseases by direct antibiosis or mycoparasitism, as well as indirect IR $(37,51)$. Trichoderma harzianum is the most commonly studied and most effective biocontrol agent available for use against a wide variety of plant diseases $(15,40)$. The T. harzanium T39 isolate, initially characterized as a control agent of gray mold on grapevine (14), has been shown to effectively control other foliar pathogens when sprayed onto various crops $(10,47)$, applied as a soil drench $(12,17)$, applied directly to tubers (19), or even dispersed by honeybees (50).

Plant-Trichoderma spp. interaction is known to correlate with systemic modulations of the plant proteome and transcriptome $(23,51)$. For instance, the interaction between T39 and grapevine was recently shown to be related to complex transcriptional repro- 
gramming (41), affecting mainly proteins associated with stress responses, photosynthesis, redox signaling, and energy metabolism (45). The hormonal and molecular pathways involved in Trichoderma spp.-mediated IR are usually activated by typical ISR in a JA/ET-dependent manner $(31,44,51,52)$. However, in some instances, the colonization of plant roots by Trichoderma spp. induces the expression of defense-related genes associated with the SA and JA/ET pathways, allowing for complex cross-talk between the plant and the biocontrol organism (23). In addition, the effects of Trichoderma spp.-based treatments on the expression levels of defense-related genes vary with the type of treatment, the type of tissue analyzed, and the plant age. For instance, SA-induced gene expression was observed in tomato foliage after long-term Trichoderma spp. treatment, either soil incorporated or applied as a seed coating $(4,54)$, but opposite results were observed when T39 was sprayed onto grapevine foliage $(45,46)$. Similarly, an SAR-like response was observed when a high rate of T. asperellum T-34 was applied but not when a lower application rate (still sufficient for IR) was used (49). In the B. cinereatomato system, the efficacies of two species of Trichoderma, including T. harzanium T22, and the transcriptional changes they induced in the plants were shown to vary greatly with the tomato cultivar and Trichoderma strain (54). In the latter system, Trichoderma spp. seed treatment led to general upregulation of SAmarker genes before infection and to the downregulation of those genes following infection, as well as the upregulation of JAdependent genes (54).

The general objective of the present work was to further characterize the IR pathway triggered by BTH and T39 in the $B$. cinerea-tomato system when those treatments are applied as soil drenches in a commonly grown cultivar. We hypothesized that there is a difference between plants' responses to BTH and T39 with regards to the genes involved in the IR pathways. In particular, we studied the role played by SA in the two cases and tested whether there is a correlation between the intensity of modulation of defense-related gene expression and the IR level following treatment with T39.

\section{MATERIALS AND METHODS}

Tomato plants and growth conditions. Tomato plants (Solanum lycopersicum) of the commonly used determinate '5811Ram' (Hazera Genetics, Brurim M.P. Shikmim, Israel) were obtained from a commercial nursery (Hishtil, Ashkelon, Israel) at 40 to 50 days after seeding and transplanted into 0.5-liter pots containing a coconut fiber-tuff potting medium. Plants were fertigated proportionally with drippers two to three times a day with 5:3:8 N-P-K fertilizer (irrigation water was mixed to have total N, $\mathrm{P}$, and $\mathrm{K}$ concentrations of 120,30 , and $150 \mathrm{mg} / \mathrm{liter}$, respectively; EC $2.2 \mathrm{dS} / \mathrm{m}$ ), allowing for 25 to $50 \%$ drainage. Plants were treated against arthropod pests once initial infestation occurred and kept at 20 to $30^{\circ} \mathrm{C}$ in a pest- and disease-free greenhouse for 1 to 2 months before treatment with inducers.

Treatment with inducers. The inducer treatments were applied to the plants as soil drenches 4 days before inoculation and again 2 to $4 \mathrm{~h}$ before the plants were inoculated with the pathogen. Drench treatments were carried out by applying $5 \mathrm{ml}$ of liquid to the wet potting medium in the root zone of the plants and preventing excess liquid from draining from the bottom of the pots. Treatments included the application of suspensions of Trichodex (T. harzianum T39) at concentrations of 0.04 and $0.4 \%$. The activity of unformulated T. harzianum T39 conidia at these concentrations is similar to the activity of the formulated product in terms of IR (16). An aqueous solution of BTH (Bion $50 \mathrm{WG}$; Syngenta Crop Protection, Switzerland) was used at a concentration of $0.01 \%(1,32)$. Water was applied as a control.

B. cinerea infection. B. cinerea (isolate BcI16) was cultured on potato dextrose agar (Difco Laboratories, Detroit) in petri dishes and incubated at $20^{\circ} \mathrm{C}$ for 10 days. Conidia were harvested in distilled water and filtered through cheesecloth and the concentration of the conidia was determined using a hemocytometer under a light microscope. The concentration of the conidia was adjusted to $10^{6}$ conidia $/ \mathrm{ml}$ in a solution of $0.5 \%$ glucose and $0.25 \% \mathrm{~K}_{2} \mathrm{HPO}_{4}$ and that suspension was then incubated at room temperature for $2 \mathrm{~h}$ without shaking. Glucose and $\mathrm{K}_{2} \mathrm{HPO}_{4}$ have been shown to facilitate the germination of $B$. cinerea conidia and subsequent leaf infection (14). Five to seven leaflets per treatment from the fourth leaf of tomato plants were excised and immediately put through a plastic net placed on wet, absorbent paper in a plastic box. Each tomato leaflet was inoculated with 4 to 5 droplets of $10 \mu \mathrm{l}$ of inoculum. Disease severity was recorded at 3, 4, 5, and 6 days postinoculation (dpi) by measuring the diameter of any necrotic lesions.

Experimental design and statistical analysis. The experiments were laid out according to a completely random design in which seven plants received each treatment. Three independent experiments were carried out. For the disease development study, average lesion area was calculated for each leaflet, plant, and replicate and the statistical analysis included all data from all experiments. Disease incidence and area under the disease progress curve data were analyzed using a one-way analysis of variance to detect significance and Fisher's protected least significant difference test for mean separation $(P \leq 0.05)$. Standard errors of the means were also calculated. The standard errors are marked with error bars in the figures and stated in Table 1. The statistical analysis was conducted using the $\mathrm{R}$ software (version 2.10.1; http://www.r-project.org). Disease reduction was calculated according to the formula percent disease reduction $=100-$ (lesion $\operatorname{area}_{T T} \times 100 /$ lesion area Control $_{1}$, where $T T$ refers to a treatment in which T39 or BTH was added to the potting mix and Control refers to the treatment in which only water was applied.

For the gene expression study, whole third leaves (three to four per treatment) were collected at $0 \mathrm{dpi}$ to study the effect of the

TABLE 1. Gene-specific primers used in quantitative real-time polymerase chain reactions

\begin{tabular}{|c|c|c|c|}
\hline Gene name & Accession number & Forward primer & Reverse primer \\
\hline RPL8 & X64562 & TGGAGGGCGTACTGAGAAAC & TCATAGCAACACCACGAACC \\
\hline Actin Tom 52 & U60482 & CATCGTCCTCAGTGGTGGTA & AGATCCTCCGATCAAGACAC \\
\hline PRla & NM-001247429.1 & CTGGTGCTGTGAAGATGTGG & TGACCCTAGCACAACCAAGA \\
\hline GluB & NM-001247876.1 & TCGAACAGGAGGAGGATCTG & TCCAGGCTTTCTCGGACTAC \\
\hline Pti5 & U89256.1 & GACATGGTGCGAGAGTATGG & CTGAAACAGAGGCGTTCACT \\
\hline Pti4 & U89255.1 & GCTGAAACACCGAAAGGAAG & TCGTACGTTCCAAGCAAAC \\
\hline TomloxA & U09026.1 & GGTTACCTCCCAAATCGTCC & TGTTTGTAACTGCGCTGTG \\
\hline ERF1 & AY044236 & ATTAGGGATTCAACGCGTAA & AGAGACCAAGGACCCСТCAT \\
\hline SAMT & NM_001247880.1 & TGGCAAGTACAAGTCCACCA & TCСАССТТTCATCAАТТСТТСС \\
\hline$P I 2$ & K03291.1 & CGACGTGTTGCACTGGTTAC & TGCCAATCCAGAAGATGGAC \\
\hline$A C O 1$ & NM-001247095.1 & GGGCTTCTTTGAGTTGGTGA & GCTTGAACAGCCTCAAGTCC \\
\hline
\end{tabular}


treatment on the whole plant. To study the disease effect on detached leaves, leaflets from fourth leaves were mock inoculated or inoculated (five to seven per treatment) and harvested at $1 \mathrm{dpi}$. The harvested leaf tissue was frozen in liquid nitrogen and stored at $-80^{\circ} \mathrm{C}$.

RNA isolation and quantitative PCR analysis. Leaves collected and stored as described above were ground in liquid nitrogen and total RNA was extracted using the ISOLATE Kit (Bioline, London). The plant effect on gene expression was tested and found to be negligible: the average of the relative expressions of the genes of interest in individual plants showed low variability and was 83 to $104 \%$ of the relative expressions in the pooled plants. Therefore, we pooled the leaf tissue collected from the three independent biological replicates within each experiment to reduce noise linked to variation between individual plants.

Reverse transcription was performed in two to three 800-ng replicates of DNAse I-treated total RNA (Applied Biosystems/ Ambion, Austin, TX) using the M-MLV reverse transcriptase (Promega Corp., Madison, WI), and cDNA products were pooled to reduce noise linked to the efficiency of the reverse transcription. Quantitative (q)PCR reactions were carried out in a RotorGene Q 6000 (Qiagen, Hilden, Germany) and the reaction products were analyzed using Rotor-Gene 6000 software. Each PCR amplification was performed in duplicate in a $15-\mu$ l reaction mixture consisting of $7.5 \mu \mathrm{l}$ of Absolute Blue SYBR Green ROX qPCR Master Mix 2X (Abgene, Epsom, UK), $1 \mu$ l each of the forward and reverse primers $(3 \mu \mathrm{M}), 4 \mu \mathrm{l}$ of cDNA template, and $1.5 \mu \mathrm{l}$ of PCR-grade water. The cycling conditions were as follows: a 15 -min preincubation at $95^{\circ} \mathrm{C}$, followed by 40 cycles of $10 \mathrm{~s}$ at $95^{\circ} \mathrm{C}, 15 \mathrm{~s}$ at $60^{\circ} \mathrm{C}$, and $20 \mathrm{~s}$ at $72^{\circ} \mathrm{C}$. The amplification of one product only was confirmed by melt-curve analysis (72 to $95^{\circ} \mathrm{C}$ ). The housekeeping genes coding for ribosomal protein RPL8 (accession number U60482) and Actin Tom 52 (accession number X64562) were used for the normalization of gene expression. Primer 3 software (http://fokker.wi.mit.edu/primer3/) was used to design gene-specific primer pairs for 12 defenserelated genes: PRla, Chi9, GluB, SAMT, ACO1, ERF1, Pti4, Pti5, TomloxA, TomloxC, TomloxD, and PI2. Among the studied genes,

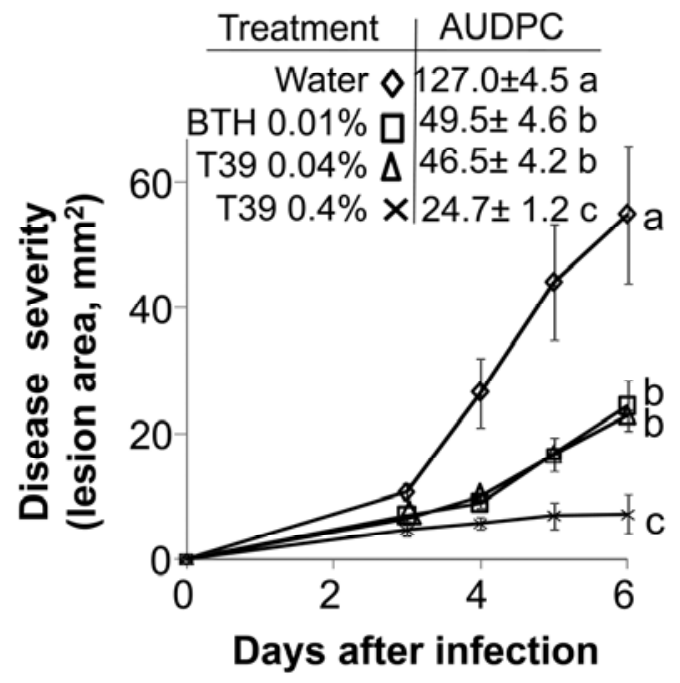

Fig. 1. Effects of benzothiadiazole (BTH) and T39 soil drenches on the development of gray mold (Botrytis cinerea) on leaves detached from treated tomato plants. Disease severity is expressed as lesion area following inoculation with a conidial suspension and as the area under the disease pressure curve (AUDPC \pm standard error) through 6 days after inoculation. Bars represent the standard error of each mean. Each mean is an average of seven replicates. Points at each sampling date followed by a common letter are significantly different according to Fisher's protected least significant difference test $(P \leq 0.05)$.
PRla, Chi9, and GluB code for PR proteins (55). SAMT codes for SA carboxyl methyltransferase, which catalyzes the methylation of SA to methyl salicylate (meSA) (5). The proteins encoded by ACO1, ERF1, Pti4, and Pti5 are related to ET synthesis and response $(22,24,53)$. The lipoxygenase-encoding genes TomloxA, Tomlox $C$, and TomloxD catalyze the first step in the octadecanoid pathway involved in responses to biotic and abiotic stress (28). Finally, PI2 encodes a proteinase inhibitor that is upregulated by wounding and JA (20).

The self-annealing of the designed primers and specificity to the chosen target were checked using the primer-blast program (http://www.ncbi.nlm.nih.gov/tools/primer-blast/index.cgi? LINK_LOC=BlastHome) and the primers were synthesized (Integrated DNA Technologies, Skokie, IL). The sequences of these primers are outlined in Table 1. Relative levels of gene expression in the treated plants compared with the untreated and mockinfected (calibrator) plants were calculated using the formula $2^{-\Delta \Delta \mathrm{Ct}}$ and the $\Delta \Delta \mathrm{Ct}$ method (35), in which $\Delta \mathrm{Ct}=\mathrm{Ct}$-specific gene $-\mathrm{Ct}$ normalizer and $\Delta \Delta \mathrm{Ct}=\Delta \mathrm{Ct}-$ arbitrary constant (the highest calibrator $\Delta \mathrm{Ct}$ ) (52). In the analysis of relative gene expression, upregulation was considered significant when the change in expression level was $\geq 1.5$-fold and downregulation was considered significant when the level of expression was $\leq 0.5$-fold.

\section{RESULTS}

Effects of BTH and T39 drench treatments on systemic resistance to gray mold. BTH and T39 significantly suppressed disease severity on detached leaves when applied twice to the growth medium; applications were made 4 days and 2 to $4 \mathrm{~h}$ before $B$. cinerea inoculation (Fig. 1). The most effective treatment was a $0.4 \%$ T39 suspension, which suppressed disease severity by $84 \%$ at 5 dpi. Applications of a $0.04 \%$ T39 suspension and a $0.01 \%$ BTH solution each reduced disease severity by $62 \%$ at 5 dpi (Fig. 1).

Effects of BTH and T39 drench treatments on the expression of defense-related genes in leaves of noninoculated tomato plants. Genes related to SA and ET were upregulated in whole plants grown on potting medium drenched with a $0.01 \%$ BTH solution (Fig. 2). The most responsive genes were PRla, the canonical marker of the SA pathway, whose expression was upregulated sevenfold, and $G l u B$, a PR gene induced by SA and ET, whose expression was upregulated fivefold. The expression of the other PR genes, as well as Pti4 and Pti5, which code for transacting factors of PR genes; the SAMT gene, which codes for SA methylase; and the ET-responsive genes TomloxC, ERF1, and $A C O 1$ were also upregulated three- to fourfold. Expression of the proteinase inhibitor gene PI2 was also increased twofold by the soil-applied BTH treatment. These results show that, as expected, drenching with BTH induced the expression of SA- and ETresponsive genes in whole plants.

The expression of the PR genes PRla and GluB was downregulated in whole plants that received the T39 suspension soil drench independently of the concentration. None of the other examined genes were affected by this treatment at $0.04 \%$ concentration. Drenching with a more concentrated T39 suspension $(0.4 \%)$ induced the expression of the JA marker genes TomloxA, TomloxD, and PI2, as well as TomloxC and SAMT (Fig. 2).

Effects of $B$. cinerea infection and drenching treatments on the expression of defense-related genes, as observed in inoculated detached leaves. Real-time PCR data analysis of gene expression in detached leaves 1 day after infection revealed that three genes that code for PR proteins (PRla, Chi9, and GluB) were transcribed at higher levels in the infected leaves than in the mock-infected (control) ones, with expression upregulated three-, two- and fourfold, respectively (Fig. 3). Similar to the expression of PR genes, the expression of Pti5, which codes for ET-responsive trans-acting factors involved in PR gene expression, was 
induced upon $B$. cinerea infection and not by the drenching treatments alone (Fig. 4). In contrast to Pti5, the expression levels of the ET-responsive factors Pti4 and ERF1 were not affected by infection alone (Fig. 4). Among the genes encoding lipoxygenases, Tomlox $D$ was the most strongly upregulated by $B$. cinerea infection. In contrast, the expression of TomloxA was strongly inhibited (Fig. 5). The gene most sensitive to $B$. cinerea infection was $P I 2$, which was upregulated 33-fold upon infection (Fig. 5). Analysis of the effect of the drenching treatments alone on the defense-related genes expression in detached leaves revealed that, in the absence of infection, each of those treatments had either a null or inhibitory effect (Figs. 3 to 5). The only exception was the $S A M T$ gene, whose level of expression was upregulated sixfold by both the $0.04 \%$ BTH treatment and the $0.04 \%$ T39 treatment and upregulated threefold by the $0.4 \%$ T39 treatment.

Effect of drenching treatments on the expression of defenserelated genes upon gray mold infection. The drench treatments increased the induction of the expression of PR genes by $B$. cinerea infection. Plants treated with $0.4 \%$ T39 suspension showed the strongest effect: upon B. cinerea infection, PRla, CHI9, and $G l u B$ were upregulated by 30 -fold (from 0.1 - to 3 -fold increase), 7-fold (from 0.3- to 2-fold increase), and 28-fold (from 0.1- to 2.8 -fold increase), respectively, compared with an average of 3 -fold increased expression in untreated plants (Fig. 3). The $0.04 \%$ T39 treatment had a weaker effect upon $B$. cinerea infection; PRla, Chi9, and GluB were upregulated by 8-fold (from 0.4-

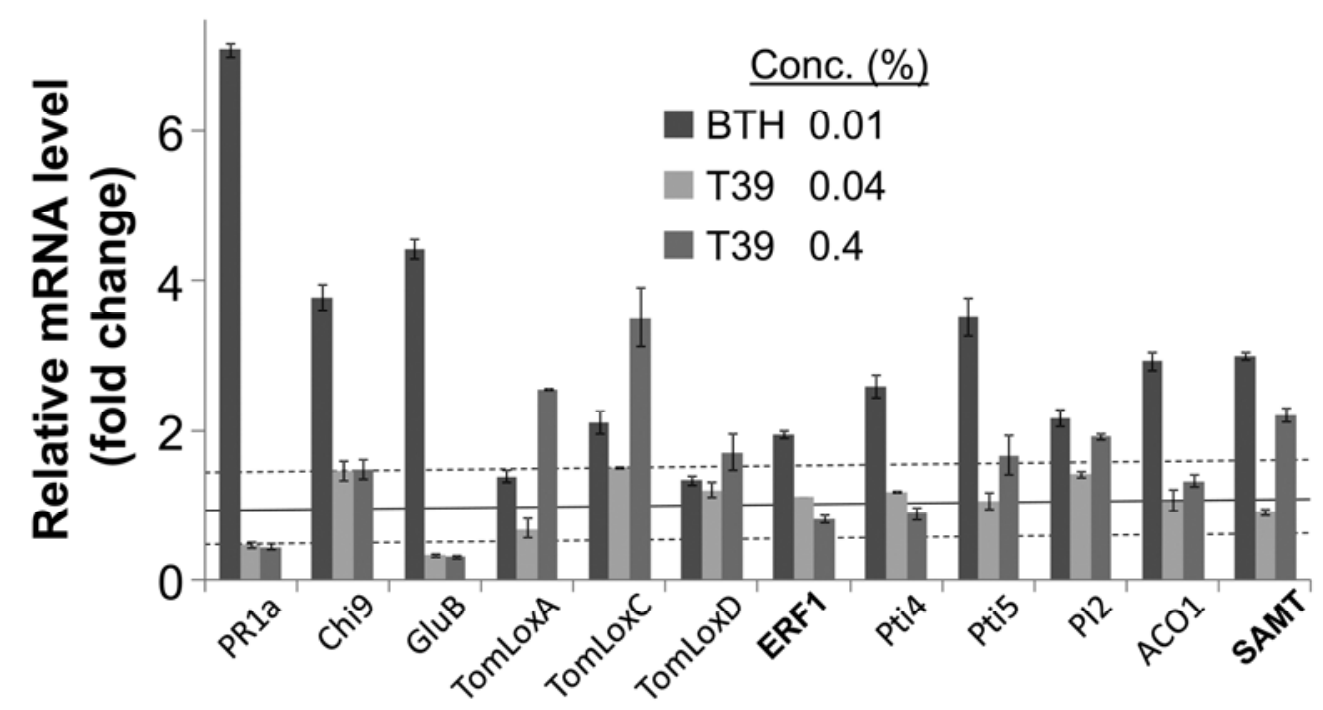

Fig. 2. Effects of benzothiadiazole (BTH) and T39 soil drenches on the expression of defense-related genes in whole tomato plants. Total RNA was isolated from the third uninfected leaves and subjected to quantitative polymerase chain reaction (qPCR) analysis. Fold-change is expressed relative to expression levels observed in plants grown on water-drenched soil. Mean levels of relative expression from five qPCR experiments are presented. Bars represent the standard error of the mean.
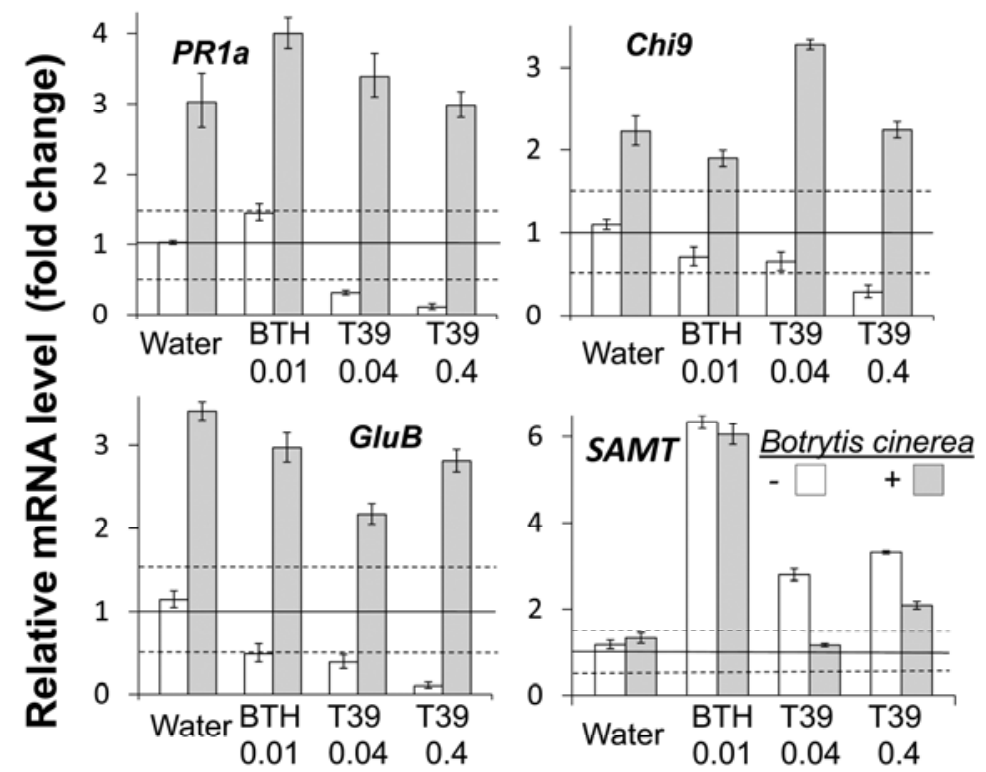

\section{Inducer and concentration (\%)}

Fig. 3. Effects of Botrytis cinerea infection (1 day postinoculation) on the expression of defense-related genes. Expression levels of the salicylic acid-related genes PRla, Chi9, GluB, and SAMT were analyzed in plants grown in drenched soil in the absence (-) or presence (+) of B. cinerea infection. Total RNA was isolated from leaves and subjected to quantitative polymerase chain reaction (qPCR) analysis. Fold-change is expressed relative to the level of expression observed in uninfected plants grown in water-drenched soil. Mean levels of relative expression from three qPCR experiments are presented. Bars represent the standard error of the mean. 
to 3-fold increase), 5.5-fold (from 0.6- to 3-fold increase), and 5.5-fold (from 0.4 to 2-fold increase), respectively. The BTH treatment had the weakest effect, affecting the upregulation of PRla and Chi9, by 2.7-fold and GluB by 6.6-fold.

The induction of the expression of Pti5 upon infection was also sensitive to the soil treatment; the expression levels of this gene were slightly higher in infected leaves detached from the 0.04 and $0.4 \%$ T39-treated plants (17- and 18-fold, respectively) than in the infected plants that had not been treated with an inducer (13-fold difference) and were strongly increased by the BTH treatment, which led to a 24-fold increase. Although the expression of the other ET-responsive factors, Pti4 and ERF1, was inhibited by the drenching treatments and remained very low in all cases (Fig. 4), they were induced by the combination of drenching and infection: threefold in the case of the BTH treatment, eight- and threefold in the case of the $0.04 \%$ T39 drench, and five- and sixfold in the case of the $0.04 \% \mathrm{~T} 39$ and $0.4 \% \mathrm{~T} 39$ treatments, respectively. Expression of the $A C O 1$ gene, which is responsible for ET synthesis, was upregulated twofold upon infection in leaves of untreated plants and BTH-treated plants. In contrast, the combination of T39 drenching and gray mold infection led to a threefold increase in expression in the case of the $0.04 \%$ T39 treatment and a fivefold increase in expression in the case of the $0.4 \%$ T39 treatment (Fig. 4).

Neither of the T39 treatments had any effect on the upregulation of PI2, the most infection-responsive gene in our study. In contrast, treatment with BTH led to an 86-fold increase in the expression of this gene upon infection (Fig. 5). The expression of
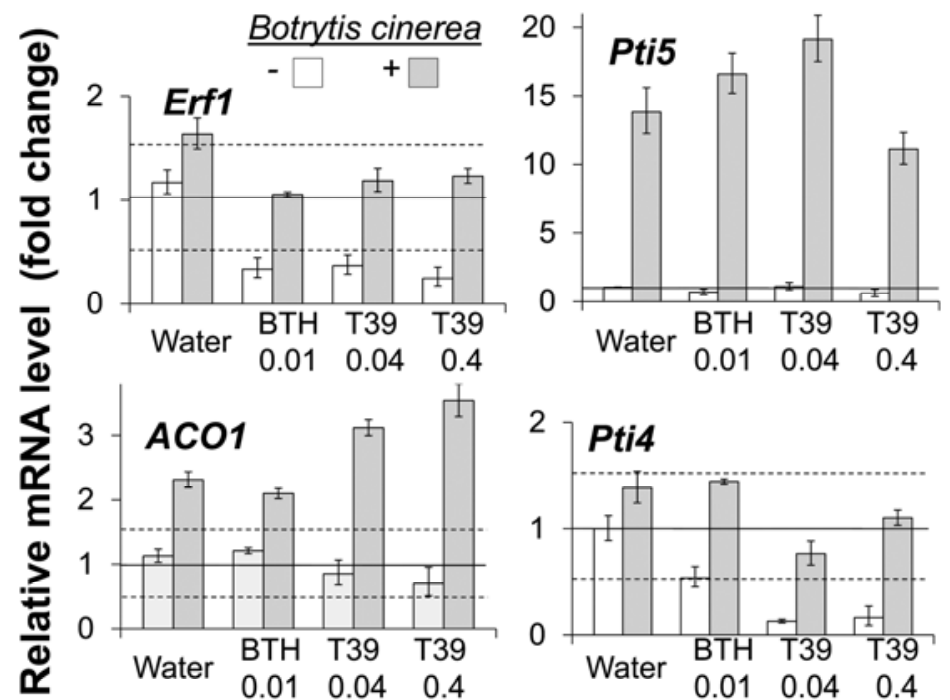

\section{Inducer and concentration (\%)}

Fig. 4. Effects of Botrytis cinerea infection (1 day postinoculation) on the expression of ethylene-related genes. Expression levels of ERF1, Pti4, Pti5, and ACO1 were analyzed in plants grown in drenched soil in the absence $(-)$ or presence $(+)$ of $B$. cinerea infection. Total RNA was isolated from leaves and subjected to quantitative polymerase chain reaction (qPCR) analysis. Fold-change is expressed relative to the level of expression observed in uninfected plants grown in waterdrenched soil. Mean levels of relative expression from three qPCR experiments are presented. Bars represent the standard error of the mean.

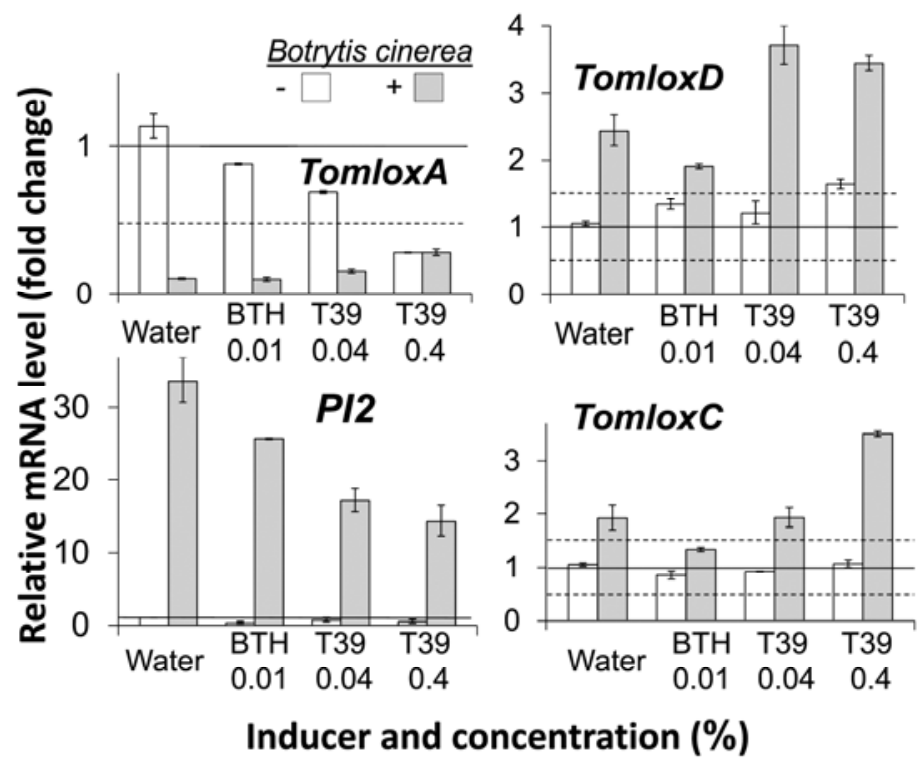

Fig. 5. Effects of Botrytis cinerea infection (1 day postinoculation) on the expression of lipoxygenase and proteinase-inhibitor genes. Expression levels of TomloxA, TomloxC, TomloxD, and PI2 were analyzed in plants grown in drenched soil in the absence (-) or presence (+) of B. cinerea infection. Total RNA was isolated from leaves and subjected to quantitative polymerase chain reaction (qPCR) analysis. Fold-change is expressed relative to the level of expression observed in uninfected plants grown on water-drenched soil. Mean levels of relative expression from three qPCR experiments are presented. Bars represent the standard error of the mean. 
Tomlox $C$ and TomloxD was induced by $B$. cinerea infection to the same extent (two- to threefold) in the control and T39-treated leaves, whereas the levels of expression of these genes upon infection decreased in the BTH-treated leaves (Fig. 5). Finally, the expression of TomloxA was strongly repressed by $B$. cinerea infection in the control, BTH, and $0.04 \%$ T39 plants. However, this repression of expression due to infection was blocked in the leaves treated with $0.4 \% \mathrm{~T} 39$.

\section{DISCUSSION}

Expression levels of defense-related genes in plants often reflect the state of the plant's awareness of biotic and abiotic stresses. In the present work, we studied the mode of action by which drench applications of the chemical BTH and drench applications of the biocontrol agent $T$. harzianum T39 induce resistance to $B$. cinerea infection in tomato leaves. In whole plants, we found that the expression of 12 defense-related genes was modulated as expected according to the nature of the treatment: the SAanalogue BTH upregulated SA-inducible genes, whereas T39 upregulated JA-inducible genes. In infected leaves, BTH-mediated IR correlated with the priming of the expression of ET- and JA-responsive genes, whereas T39-mediated IR was accompanied by the priming of the expression of SA-responsive genes.

In whole tomato plants grown in BTH-drenched growth medium, the systemic induction of SA-regulated gene expression by the SA analogue was observed together with the induction of ETregulated gene expression and the inhibition of JA-regulated gene expression. Treatment with SA chemical analogues such as BTH has been correlated with SAR in parsley cell cultures and, in Arabidopsis thaliana, BTH was shown to prime the accumulation of PAL mRNA upon treatment with an elicitor or pathogen infection $(27,30)$. In the case of drench applications of T39, expression of SA-responsive genes was inhibited in whole plants and the JA- and ET-responsive genes TomloxA and TomloxC as well as the SAMT-encoding gene were upregulated following the application of a suspension containing a high concentration of conidia $(0.4 \%)$.

Similar upregulation of TomloxA and, to a lesser extent, TomloxC was observed in tomato plants of different cultivars grown from seed coated with $T$. harzianum T22 (54). In that work, gene expression was only weakly induced by the treatment in a breeding line that was not responsive to the biocontrol agent. We observed a similar correlation between the strength of IR and the degree to which the level of gene expression was affected by the treatment.

In addition, the upregulation of SAMT in plants treated with a highly concentrated T39 suspension most probably reflects the induction of methylation of SA to yield meSA. In tobacco, meSA produced from SA by SAMT was found to act as a mobile signal critical for the development of SAR. Once transported systemically to distant tissue by the vascular system, meSA is reconverted into active SA, triggering the expression of defense genes in these tissues (42). Because demethylation of meSA to SA is generally considered to be a prerequisite for SAR $(42,43)$, this suggests an inhibition of SAR by T39 treatment, in line with the inhibition of SA-responsive gene expression. Therefore, in the present study, drench applications of a $0.4 \%$ T39 suspension led to the induction of JA- and ET-responsive genes in whole plants, in accordance with the general consensus that this biocontrol agent works through the ISR pathway.

In leaves detached from plants that had received the drenching treatments, SAMT was the only gene to be upregulated. BTH drenching, in particular, had the strongest effect on the level of $S A M T$ transcription, which remained high upon $B$. cinerea inoculation. In addition, the upregulation of the SA-regulated genes due to inoculation was not affected by the treatment. These results suggest that BTH drenching treatment leads to transport of SA in the form of meSA in the detached leaves without inducing SAR there. A similar absence of any correlation between IR associated with BTH and SA-induced gene expression was described in a previous study that used the same inoculation assay (7). In that work, PRla expression was found to be induced by an extreme concentration of BTH but not by the concentration active in IR. Accordingly, the relationship between the IR associated with SA analogues and SA-dependent SAR is still controversial $(21,34)$. In the present study, upregulation of the five genes all related to the ET and JA pathways (GluB, ERF1, Pti4, Pti5, and PI2) was observed upon infection in the leaves detached from plants grown on BTH-drenched soil compared with the leaves of untreated plants. This so-called priming effect was strongest for Pti5 and $P I 2$. These two genes are known to play a major role in defending the plant against $B$. cinerea infection $(6,18)$.

In the case of drenching with T39 suspensions, strong priming effects on PRla, Chi9, and GluB expression were observed. The level of priming was proportional to the concentration of the T39 suspension applied and correlated with the level of IR. Upregulation of SAMT was observed as well upon T39 drench treatment but, when plants treated with T39 were inoculated, their levels of SAMT mRNA fell back to the level observed in untreated plants. Because upregulation of the PR genes was observed in that case, it suggests an increase in SA level. Therefore, SAMT appears to be a good marker for SA involvement in the IR molecular pathways. The priming effect of the T39 treatment on defenseand microbial recognition-related gene expression upon infection with $B$. cinerea is expected for a biocontrol agent triggering the ISR pathway (3) and has been reported by others $(38,41,52)$. However, the recent study of the effect of T22 treatment on gene expression in IR against B. cinerea showed opposite results, mainly upregulation of SA-marker genes before infection and the downregulation of those genes following infection (54). The discrepancy with our results can probably be explained by the mode of application of the biocontrol agent as well as the type of the bioassay for gray mold infection. Expression of the ET-related genes EFRI and ACOI was also primed by the T39 treatments. In addition, the IR to gray mold observed in plants treated with a $0.4 \%$ T39 suspension correlated with a maintained level of TomloxA expression. This is in accordance with the suggested role of TomloxA in controlling the spread of beneficial fungi in roots (33). Similarly, in the case of Plasmopara viticola-grapevine interaction, induction of Lox9 gene transcription was observed in T39-treated plants (46). Toxic effects of compounds derived from the lipoxygenase pathway, such as C6-volatiles, on $B$. cinerea have also been described (29).

In conclusion, SA was involved in an opposite manner in the BTH- and T39-mediated IR in the tomato- $B$. cinerea system. Prior to inoculation, the SA-responsive genes were systemically upregulated by BTH and inhibited by T39. Following inoculation in the detached leaves, BTH-mediated IR was found independent of SA, probably involving SA transport in the form of meSA, while T39 induced strong priming of the SA-responsive gene expression. In addition, the present study shows a clear correlation between the concentration of the applied T39 suspension, the rate of IR in tomato leaves, and the priming of the expression of genes related to SA and ET. Practically, because both control agents induce resistance but do so in different ways, they should be applied in a way that allows for constant exposure and protection of the host plant, including during periods preceding infection by $B$. cinerea. This will allow the activation of the different resistance genes prior to and during the infection process.

\section{ACKNOWLEDGMENTS}

Publication of the ARO number 513/13. This research was funded by the Autonomous Province of Trento, Call for Proposal Major Projects 2006, Project ENVIROCHANGE. We thank R. Shulhani and M. Borenshtein for their help in taking care of the plants. 


\section{LITERATURE CITED}

1. Abo-Elyousr, K. A. M., and El-Hendawy, H. H. 2008. Integration of Pseudomonas fluorescens and acibenzolar-S-methyl to control bacterial spot disease of tomato. Crop Prot. 27:1118-1124.

2. Achuo, E. A., Audenaert, K., Meziane, H., and Höfte, M. 2004. The salicylic acid-dependent defence pathway is effective against different pathogens in tomato and tobacco. Plant Pathol. 53:65-72.

3. Ahn, I. P., Lee, S. W., and Suh, S. C. 2007. Rhizobacteria-induced priming in Arabidopsis is dependent on ethylene, jasmonic acid, and NPR1. Mol. Plant-Microbe Interact. 20:759-768.

4. Alfano, G., Ivey, M. L. L., Cakir, C., Bos, J. I. B., Miller, S. A., Madden, L. V., Kamoun, S., and Hoitink, H. A. J. 2007. Systemic modulation of gene expression in tomato by Trichoderma hamatum 382. Phytopathology 97:429-437.

5. Ament, K., Krasikov, V., Allmann, S., Rep, M., Takken, F. L., and Schuurink, R. C. 2010. Methyl salicylate production in tomato affects biotic interactions. Plant J. 62:124-134.

6. Asselbergh, B., Curvers, K., Franca, S. C., Audenaert, K., Vuylsteke, M., Van Breusegem, F., and Höfte, M. 2007. Resistance to Botrytis cinerea in sitiens, an abscisic acid-deficient tomato mutant, involves timely production of hydrogen peroxide and cell wall modifications in the epidermis. Plant Physiol. 144:1863-1877.

7. Audenaert, K., De Meyer, G. B., and Höfte, M. 2002. Abscisic acid determines basal susceptibility of tomato to Botrytis cinerea and suppresses salicylic acid-dependent signaling mechanisms. Plant Physiol. 128:491-501.

8. Barilli, E., Sillero, J. C., and Rubiales, D. 2010. Induction of systemic acquired resistance in pea against rust (Uromyces pisi) by exogenous application of biotic and abiotic inducers. J. Phytopathol. 158:30-34.

9. Boava, L. P., Kuhn, O. J., Pascholati, S. F., Di Piero, R. M., and Furtado, E. L. 2009. Effect of acibenzolar-S-methyl and Saccharomyces cerevisiae on the activation of eucalyptus defences against rust. Australas. Plant Pathol. 38:594-602.

10. Brand, M., Messika, Y., Elad, Y., David, D. R., and Sztejnberg, A. 2009. Spray treatments combined with climate modification for the management of Leveillula taurica in sweet pepper. Eur. J. Plant Pathol. 124:309-329.

11. Conrath, U., Beckers, G. J. M., Flors, V., Garcia-Agustin, P., Jakab, G., Mauch, F., Newman, M. A., Pieterse, C. M. J., Poinssot, B., Pozo, M. J., Pugin, A., Schaffrath, U., Ton, J., Wendehenne, D., Zimmerli, L., and Mauch-Mani, B. 2006. Priming: Getting ready for battle. Mol. PlantMicrobe Interact. 19:1062-1071.

12. De Meyer, G., Bigirimana, J., Elad, Y., and Höfte, M. 1998. Induced systemic resistance in Trichoderma harzianum $\mathrm{T} 39$ biocontrol of Botrytis cinerea. Eur. J. Plant Pathol. 104:279-286.

13. Durrant, W. E., and Dong, X. 2004. Systemic acquired resistance. Annu. Rev. Phytopathol. 42:185-209.

14. Elad, Y. 1994. Biological control of grape gray mold by Trichoderma harzianum. Crop Prot. 13:35-38.

15. Elad, Y. 2000. Biological control of foliar pathogens by means of Trichoderma harzianum and potential modes of action. Crop Prot. 19:709-714.

16. Elad, Y. 2000. Trichoderma harzianum T39 preparation for biocontrol of plant diseases-control of Botrytis cinerea, Sclerotinia sclerotiorum and Cladosporium fulvum. Biocontrol Sci. Technol. 10:499-507.

17. Elad, Y., Kirshner, B., and Sztejnberg, A. 1998. Management of powdery mildew and gray mold of cucumber by Trichoderma harzianum T39 and Ampelomyces quisqualis AQ10. Biocontrol 43:241-251.

18. El Oirdi, M., Abd El Rahman, T., Rigano, L., El Hadrami, A., Rodriguez, M. C., Daayf, F., Vojnov, A., and Bouarab, K. 2011. Botrytis cinerea manipulates the antagonistic effects between immune pathways to promote disease development in tomato. Plant Cell 23:2405-2421.

19. Etebarian, H. R., Scott, E. S., and Wicks, T. J. 2000. Trichoderma harzianum T39 and T. virens DAR 74290 as potential biological control agents for Phytophthora erythroseptica. Eur. J. Plant Pathol. 106:329-337.

20. Farmer, E. E., and Ryan, C. A. 1992. Octadecanoid precursors of jasmonic acid activate the synthesis of wound-inducible proteinaseinhibitors. Plant Cell 4:129-134.

21. Gozzo, F. 2003. Systemic acquired resistance in crop protection: From nature to a chemical approach. J. Agric. Food Chem. 51:4487-4503.

22. Gu, Y. Q., Yang, C., Thara, V. K., Zhou, J., and Martin, G. B. 2000. Pti4 is induced by ethylene and salicylic acid, and its product is phosphorylated by the Pto kinase. Plant Cell 12:771-785.

23. Hermosa, R., Viterbo, A., Chet, I., and Monte, E. 2012. Plant-beneficial effects of Trichoderma and of its genes. Microbiology 158:17-25.

24. Huang, Z. J., Zhang, Z. J., Zhang, X. L., Zhang, H. B., Huang, D. F., and Huang, R. F. 2004. Tomato TERF1 modulates ethylene response and enhances osmotic stress tolerance by activating expression of downstream genes. FEBS Lett. 573:110-116.

25. Ji, P., Yin, J., and Kone, D. 2011. Application of acibenzolar-S-methyl and standard fungicides for control of Phytophthora blight on squash. Crop
Prot. 30:1601-1605.

26. Jung, H. W., Tschaplinski, T. J., Wang, L., Glazebrook, J., and Greenberg, J. T. 2009. Priming in systemic plant immunity. Science 324:89-91.

27. Katz, V. A., Thulke, O. U., and Conrath, U. 1998. A benzothiadiazole primes parsley cells for augmented elicitation of defense responses. Plant Physiol. 117:1333-1339.

28. Kazan, K., and Manners, J. M. 2008. Jasmonate signaling: Toward an integrated view. Plant Physiol. 146:1459-1468.

29. Kishimoto, K., Matsui, K., Ozawa, R., and Takabayashi, J. 2008. Direct fungicidal activities of C6-aldehydes are important constituents for defense responses in Arabidopsis against Botrytis cinerea. Phytochemistry 69:2127-2132.

30. Kohler, A., Schwindling, S., and Conrath, U. 2002. Benzothiadiazoleinduced priming for potentiated responses to pathogen infection, wounding, and infiltration of water into leaves requires the NPR1/NIM1 gene in Arabidopsis. Plant Physiol. 128:1046-1056.

31. Korolev, N., David, D. R., and Elad, Y. 2008. The role of phytohormones in basal resistance and Trichoderma-induced systemic resistance to Botrytis cinerea in Arabidopsis thaliana. Biocontrol 53:667-683.

32. Lawton, K. A., Friedrich, L., Hunt, M., Weymann, K., Delaney, T., Kessmann, H., Staub, T., and Ryals, J. 1996. Benzothiadiazole induces disease resistance in Arabidopsis by activation of the systemic acquired resistance signal transduction pathway. Plant J. 10:71-82.

33. Leon-Morcillo, R. J., Angel, J., Martin-Rodriguez, Vierheilig, H., Ocampo, J. A., and Garcia-Garrido, J. M. 2012. Late activation of the 9-oxylipin pathway during arbuscular mycorrhiza formation in tomato and its regulation by jasmonate signalling. J. Exp. Bot. 63:3545-3558.

34. Liu, C. L., Ruan, Y., Lin, Z. J., Wei, R., Peng, Q., Guan, C. Y., and Ishii, H. 2008. Antagonism between acibenzolar-S-methyl-induced systemic acquired resistance and jasmonic acid-induced systemic acquired susceptibility to Colletotrichum orbiculare infection in cucumber. Physiol. Mol. Plant Pathol. 72:141-145.

35. Livak, K. J., and Schmittgen, T. D. 2001. Analysis of relative gene expression data using real-time quantitative PCR and the 2(-Delta Delta C(T)) method. Methods 25:402-408.

36. Loake, G., and Grant, M. 2007. Salicylic acid in plant defence-the players and protagonists. Curr. Opin. Plant Biol. 10:466-472.

37. Lorito, M., Woo, S. L., Harman, G. E., and Monte, E. 2010. Translational research on Trichoderma: From 'omics' to the field. Annu. Rev. Phytopathol. 48:395-417.

38. Malmierca, M. G., Cardoza, R. E., Alexander, N. J., McCormick, S. P., Hermosa, R., Monte, E., and Gutierrez, S. 2012. Involvement of Trichoderma Trichothecenes in the biocontrol activity and induction of plant defense related genes. Appl. Environ. Microbiol. 78:4856-4868.

39. Malolepsza, U. 2006. Induction of disease resistance by acibenzolar-Smethyl and o-hydroxyethylorutin against Botrytis cinerea in tomato plants. Crop Prot. 25:956-962.

40. Moran-Diez, E., Rubio, B., Dominguez, S., Hermosa, R., Monte, E., and Nicolas, C. 2012. Transcriptomic response of Arabidopsis thaliana after $24 \mathrm{~h}$ incubation with the biocontrol fungus Trichoderma harzianum. J. Plant Physiol. 169:614-620.

41. Palmieri, M. C., Perazzolli, M., Matafora, V., Moretto, M., Bachi, A., and Pertot, I. 2012. Proteomic analysis of grapevine resistance induced by Trichoderma harzianum T39 reveals specific defence pathways activated against downy mildew. J. Exp. Bot. 63:6237-6251.

42. Park, S. W., Kaimoyo, E., Kumar, D., Mosher, S., and Klessig, D. F. 2007. Methyl salicylate is a critical mobile signal for plant systemic acquired resistance. Science 318:113-116.

43. Park, S. W., Liu, P. P., Forouhar, F., Vlot, A. C., Tong, L., Tietjen, K., and Klessig, D. F. 2009. Use of a synthetic salicylic acid analog to investigate the roles of methyl salicylate and its esterases in plant disease resistance. J. Biol. Chem. 284:7307-7317.

44. Perazzolli, M., Dagostin, S., Ferrari, A., Elad, Y., and Pertot, I. 2008. Induction of systemic resistance against Plasmopara viticola in grapevine by Trichoderma harzianum $\mathrm{T} 39$ and benzothiadiazole. Biol. Control 47:228-234.

45. Perazzolli, M., Moretto, M., Fontana, P., Ferrarini, A., Velasco, R., Moser, C., Delledonne, M., and Pertot, I. 2012. Downy mildew resistance induced by Trichoderma harzianum T39 in susceptible grapevines partially mimics transcriptional changes of resistant genotypes. BMC Genomics 13:660. Online publication. doi:10.1186/1471-2164-13-660

46. Perazzolli, M., Roatti, B., Bozza, E., and Pertot, I. 2011. Trichoderma harzianum $\mathrm{T} 39$ induces resistance against downy mildew by priming for defense without costs for grapevine. Biol. Control 58:74-82.

47. Pertot, I., Fiamingo, F., Amsalem, L., Maymon, M., Freeman, S., Gobbin, D., and Elad, Y. 2007. Sensitivity of two Podosphaera aphanis populations to disease control agents. J. Plant Pathol. 89:85-96.

48. Ryals, J. A., Neuenschwander, U. H., Willits, M. G., Molina, A., Steiner, H. Y., and Hunt, M. D. 1996. Systemic acquired resistance. Plant Cell 8:1809-1819. 
49. Segarra, G., Casanova, E., Bellido, D., Odena, M. A., Oliveira, E., and Trillas, I. 2007. Proteome, salicylic acid, and jasmonic acid changes in cucumber plants inoculated with Trichoderma asperellum strain T34. Proteomics 7:3943-3952.

50. Shafir, S., Dag, A., Bilu, A., Abu-Toamy, M., and Elad, Y. 2006. Honey bee dispersal of the biocontrol agent Trichoderma harzianum T39: Effectiveness in suppressing Botrytis cinerea on strawberry under field conditions. Eur. J. Plant Pathol. 116:119-128.

51. Shoresh, M., Harman, G. E., and Mastouri, F. 2010. Induced systemic resistance and plant responses to fungal biocontrol agents. Annu. Rev. Phytopathol. 48:21-43.

52. Shoresh, M., Yedidia, I., and Chet, I. 2005. Involvement of jasmonic acid/ethylene signaling pathway in the systemic resistance induced in cucumber by Trichoderma asperellum T203. Phytopathology 95:76-84.

53. Thara, V. K., Tang, X. Y., Gu, Y. Q., Martin, G. B., and Zhou, J. M. 1999. Pseudomonas syringae pv. tomato induces the expression of tomato EREBP-like genes Pti4 and Pti5 independent of ethylene, salicylate and jasmonate. Plant J. 20:475-483.

54. Tucci, M., Ruocco, M., De Masi, L., De Palma, M., and Lorito, M. 2011. The beneficial effect of Trichoderma spp. on tomato is modulated by the plant genotype. Mol. Plant Pathol. 12:341-354.

55. Van Loon, L. C., Bakker, P. A. H. M., and Pieterse, C. M. J. 1998. Systemic resistance induced by rhizosphere bacteria. Annu. Rev. Phytopathol. 36:453-483 